\section{RMD Open}

Rheumatic \& Musculoskeletal Diseases

\title{
Secukinumab in the treatment of
} psoriatic arthritis: efficacy and safety results through 3 years from the year 1 extension of the randomised phase III FUTURE 1 trial

\author{
Philip J Mease, ${ }^{1}$ Arthur Kavanaugh, ${ }^{2}$ Andreas Reimold, ${ }^{3}$ Hasan Tahir, ${ }^{4}$ \\ Jürgen Rech, ${ }^{5}$ Stephen Hall, ${ }^{6}$ Piet Geusens, ${ }^{7,8}$ Pascale Pellet, ${ }^{9}$ Evie Maria Delicha, ${ }^{9}$ \\ Shephard Mpofu, ${ }^{9}$ Luminita Pricop, ${ }^{10}$ On behalf of the FUTURE 1 study group
}

To cite: Mease PJ, Kavanaugh A, Reimold A, et al. Secukinumab in the treatment of psoriatic arthritis: efficacy and safety results through 3 years from the year 1 extension of the randomised phase III FUTURE 1 trial. RMD Open 2018;4:e000723. doi:10.1136/ rmdopen-2018-000723

- Prepublication history and additional material for this paper are available online. To view these files, please visit the journal online (http://dx.doi. org/10.1136/rmdopen-2018000723).

Received 14 May 2018 Revised 28 June 2018 Accepted 2 July 2018
Check for updates

(c) Author(s) (or their employer(s)) 2018. Re-use permitted under CC BY-NC. No commercial re-use. See rights and permissions. Published by BMJ.

For numbered affiliations see end of article.

Correspondence to Professor Philip J Mease; pmease@philipmease.com

\section{ABSTRACT}

Objective To assess the long-term ( 3 year) efficacy and safety of secukinumab in patients with active psoriatic arthritis (PsA) in the extension phase of the FUTURE 1 study (NCT01892436).

Methods Following the 2-year core trial, eligible patients receiving subcutaneous secukinumab 150 or $75 \mathrm{mg}$ entered a 3-year extension phase. Results are presented for key efficacy and safety endpoints at week 156. Results In total, 460 patients entered the extension study; 308 patients originally randomised to secukinumab were assessed for efficacy. Sustained improvements in all efficacy endpoints were achieved with secukinumab through week 156 . Overall, $76.8 \% / 54.9 \%$ (secukinumab $150 \mathrm{mg}$ ) and $65.2 \% / 39.0 \%$ (secukinumab $75 \mathrm{mg}$ ) of patients achieved an American College of Rheumatology (ACR) 20/50 response (multiple imputation data); ACR20 responses were sustained irrespective of previous antitumour necrosis factor exposure. Improvements in quality of life and physical function were also sustained through week 156. Radiographic results (observed data; van der Heijde modified total Sharp score (mTSS)) showed that $78.1 \%$ (secukinumab $150 \mathrm{mg}$ ) and $74.8 \%$ (secukinumab $75 \mathrm{mg})$ of patients had no radiographic progression $(\leq 0.5$ increase in mTSS) through week 156. Exposure-adjusted incidence rates for selected adverse events per 100 patient-years (secukinumab 150/75 mg) were serious infections (1.7/1.6), Candida infections (1.4/0.7), Crohn's disease $(0 / 0.3)$, ulcerative colitis $(0 / 0.3)$ and major adverse cardiac events $(0.3 / 0.8)$.

Conclusion Subcutaneous secukinumab provided sustained improvements in the signs and symptoms, quality of life and physical function of patients with active PsA with low rate of radiographic disease progression through 3 years. Secukinumab was well tolerated with no new safety signals.

\section{INTRODUCTION}

Psoriatic arthritis (PsA) is a chronic, inflammatory disease characterised by peripheral

\section{Key messages}

What is already known about this subject?

- Secukinumab, a fully human monoclonal IgG1 $\kappa$ antibody that selectively neutralises IL-17A, provided sustained improvements in the signs and symptoms of active psoriatic arthritis (PSA) in phase III FUTURE 1 study over 2 years.

What does this study add?

- Secukinumab $150 \mathrm{mg}$ (approved dose) sustained or further improved the clinical responses in patients with active PsA over 3 years in FUTURE 1 study, with a low rate of radiographic disease progression and safety profile consistent with previous reports.

How might this impact on clinical practice?

- This long-term (3-year) data for secukinumab in PsA adds to the growing body of evidence supporting the use of IL-17 inhibitors in PsA, as recognised in the guidelines of European League Against Rheumatism and Group for Research and Assessment of Psoriasis and Psoriatic Arthritis recommendations.

arthritis, axial disease, dactylitis, enthesitis, and skin and nail psoriasis. ${ }^{1}$ It can be associated with more serious comorbidities such as cardiovascular disease, metabolic syndrome and diabetes, ${ }^{2-4}$ and has a substantial impact on quality of life, physical function and work productivity. ${ }^{5}$ Management of PsA should ideally aim to minimise articular pain, enthesitis, structural damage, disability and dermatological symptoms. ${ }^{16-8}$ The introduction of anti-tumour necrosis factor- $\alpha$ inhibitors (anti-TNF agents) has significantly improved outcomes among patients with PsA,${ }^{6-11}$ but a proportion of patients have an inadequate response or poor tolerability to 
these agents. ${ }^{312}$ Secukinumab, a fully human monoclonal antibody that selectively neutralises interleukin IL-17A, ${ }^{13}$ has been shown to have significant efficacy in the treatment of ankylosing spondylitis, ${ }^{13} 14$ moderate to severe psoriasis ${ }^{15}$ and PsA, ${ }^{16-18}$ demonstrating a rapid onset of action and sustained responses with an acceptable safety profile across the three indications. ${ }^{19} 20$

In the randomised, placebo-controlled, phase III FUTURE 1 core study, secukinumab demonstrated rapid, significant and sustained reductions in the signs and symptoms of PsA, and inhibited radiographic progression through 2 years of treatment. ${ }^{16} 21$ The ongoing FUTURE 1 extension trial is a 3-year extension of the 2-year core trial, assessing the effect of secukinumab on the signs and symptoms, structural damage, physical function and quality of life of patients with active PsA, in addition to evaluating long-term safety. Here, we present efficacy and safety results of all doses (secukinumab 150 $\mathrm{mg}$ (approved dose) and $75 \mathrm{mg}$ ) assessed in the FUTURE 1 study through 3 years (2 years of the core study plus 1 year of the extension).

\section{METHODS}

\section{Study population}

Detailed patient eligibility criteria have been reported previously. ${ }^{16}$ Briefly, patients were $\geq 18$ years, with active PsA according to the Classification Criteria for Psoriatic Arthritis, ${ }^{22}$ with moderate to severe symptoms for $\geq 6$ months, $\geq 3$ tender joints of 78 and $\geq 3$ swollen joints of 76 , despite previous treatment with nonsteroidal anti-inflammatory drugs, disease-modifying anti-rheumatic drugs or anti-TNF agents. Concomitant use of oral glucocorticoids (up to $10 \mathrm{mg}$ /day of prednisone or equivalent) and methotrexate (up to $25 \mathrm{mg}$ /week) was permitted. Patients were excluded if they had previous therapy with biologic agents other than anti-TNF agents, treatment with more than three anti-TNF agents, active inflammatory disease other than PsA or active/history of ongoing infection. The study was approved by the institutional review board or ethics committee at each participating site (Swedish Medical Centre and University of Washington (1143210), Dallas VAMC and University of Texas Southwestern Medical Centre (\#IRB 14-025), Barts Health NHS Trust (13/WM/0365), University of Erlangen-Nuremberg (AZ: EK-13/081), Monash University (2013-08-423), University of Hasselt and Maastricht University Hospital (2013/1062); online supplementary table 1) and was conducted according to the Declaration of Helsinki. ${ }^{23}$

\section{Study oversight and design}

The randomised, double-blind FUTURE 1 study (NCT01892436) was conducted across 104 sites in North and South America, Europe, the Middle East, Australia and Asia, the design of which has been previously reported. ${ }^{16}$ Briefly, eligible patients were initially randomised to receive secukinumab $10 \mathrm{mg} / \mathrm{kg}$ intravenous (IV) loading dose at baseline and weeks 2 and 4 , followed by subcutaneous (SC) secukinumab $150 \mathrm{mg}$ or $75 \mathrm{mg}$ every 4 weeks from week 8. Placebo was given using the same IV-to-SC dosing schedule. At week 16, placebo-treated patients were re-randomised to receive SC secukinumab $150 \mathrm{mg}$ or $75 \mathrm{mg}$ from either week 16 for placebo non-responders ( $<20 \%$ improvement from baseline in both tender and swollen joints) or week 24 for placebo responders. Randomisation was stratified by previous anti-TNF status, with patients being anti-TNF-naïve or anti-TNF-experienced (incomplete responders who had active disease despite having received an anti-TNF agent for $\geq 3$ months, or who had stopped treatment due to safety and tolerability reasons). At the end of the 2-year core trial, eligible patients entered the 3-year extension phase. From week 156 , patients not adequately responding to secukinumab $75 \mathrm{mg}$ could be up-titrated to secukinumab $150 \mathrm{mg}$, at the discretion of investigators. See online supplementary figure 1 for the extension study design.

\section{Endpoints and assessments}

Efficacy results at week 156 are reported for patients who were originally randomised to $10 \mathrm{mg} / \mathrm{kg}$ IV loading followed by SC $150 \mathrm{mg}$ and $75 \mathrm{mg}$ maintenance with secukinumab. The primary efficacy endpoints of this extension study were the proportion of patients treated with secukinumab $150 \mathrm{mg}$ and $75 \mathrm{mg}$ achieving an American College of Rheumatology (ACR) 20/50/70 response over time. ${ }^{24}$ Week 156 assessments also included the proportion of patients achieving Psoriatic Area and Severity Index (PASI) 75 responses, resolution of dactylitis and enthesitis and proportion of patients with minimal disease activity (MDA). Changes from baseline in Disease Activity Score in 28 joints using $\mathrm{C}$ reactive protein (DAS28-CRP), Health Assessment Questionnaire-Disability Index (HAQ-DI), Medical Outcome Short Form (36) Health Survey (SF-36) Physical Component Summary (PCS) and Mental Component Summary (MCS), and radiographic progression (measured by the van der Heijde modified total Sharp score (mTSS), which is the sum of erosion and joint space narrowing (JSN) scores).$^{25} \mathrm{X}$-rays of the hands, wrists and feet, performed at baseline and week 156 , were read centrally by two independent readers blinded to the treatment arms. The mean score was used for all analyses. Radiographic non-progressors were defined as patients with a change from baseline of $\leq 0.5$ in mTSS during the considered period, as per guideline recommendations. ${ }^{26}$ Long-term safety and tolerability was assessed over the treatment period by monitoring the frequency of treatment-emergent adverse events (AEs), serious AEs, laboratory abnormalities and vital signs.

\section{Statistical analyses}

Sample size calculation estimated that 600 patients (200 in each secukinumab group and 200 in the placebo group) were sufficient to meet primary and key secondary endpoints. Analysis of primary and other 
efficacy endpoints of the core trial have been reported previously. ${ }^{16}$ It was estimated that $460-520$ patients would be eligible for enrolment in this extension study.

Evaluations of efficacy were performed on patients enrolled in the extension with at least one efficacy assessment during the extension and who were originally randomised to $10 \mathrm{mg} / \mathrm{kg}$ IV loading at baseline and weeks 2 and 4, followed by SC $150 \mathrm{mg}$ and $75 \mathrm{mg}$ maintenance with secukinumab starting at week 8 . Efficacy data from patients who discontinued the study were considered as end of treatment period results. No formal hypotheses were planned in this extension study. In the current analysis, missing binary variables up to week 156 were imputed using multiple imputation. Summaries of continuous variables are as observed and presented as mean \pm SD. Dactylitis and enthesitis were evaluated using multiple imputation in the subgroup of patients with these symptoms at baseline. PASI response was evaluated in the subgroup of patients with at least $3 \%$ of the body surface area affected by psoriatic skin involvement.

Joint structural damage (changes from baseline in mTSS scores, erosion scores and JSN scores) and proportion of radiographic non-progressors were analysed using observed data based on all evaluable patients with data at both baseline and week 156 .

Predefined subgroup analyses were carried out on the basis of previous anti-TNF therapy (anti-TNF-naive or anti-TNF-experienced) for key efficacy endpoints.

Safety analysis included all patients (core and extension study phase) who received $\geq 1$ dose of secukinumab, with patients analysed for safety according to the actual treatment they received. As safety was collected over the treatment period and included data past week 156, safety analyses included patients who up-titrated from $75 \mathrm{mg}$ to $150 \mathrm{mg}$; therefore, patients who were up-titrated were counted in either secukinumab group depending on the timing of the event. Data for selected AEs are presented as ted incidence rates (EAIRs) exposure-adjusted incidence rate (EAIR) per 100 patient-years.

\section{RESULTS \\ Patients}

Of the 606 patients originally randomised in the FUTURE 1 core trial, $460(75.9 \%)$ patients entered the extension study (secukinumab $150 \mathrm{mg}(\mathrm{N}=162)$, secukinumab 75 $\mathrm{mg}(\mathrm{N}=148)$, placebo then secukinumab $(\mathrm{N}=150))$. Figure 1 shows a breakdown of patients who entered the extension study. Three patients who were originally randomised to secukinumab and who discontinued the study were not part of the efficacy analyses due to the lack of efficacy assessment during the extension study; reasons for discontinuation were sudden cardiac death $(150 \mathrm{mg}$ arm), patient decision (75 mg arm) and development of squamous cell carcinoma of the pharynx (75 mg arm).

Within the full analysis set (FAS) population, the reasons for discontinuation included patient decision $(n=7)$, AEs $(n=5)$, lack of efficacy $(n=5)$, physician decision $(n=2)$, pregnancy $(n=2)$ and loss to follow-up $(n=1)$. The patient demographics and baseline disease characteristics of patients entering the long-term extension phase were similar across the $150 \mathrm{mg}$ and $75 \mathrm{mg}$ arms

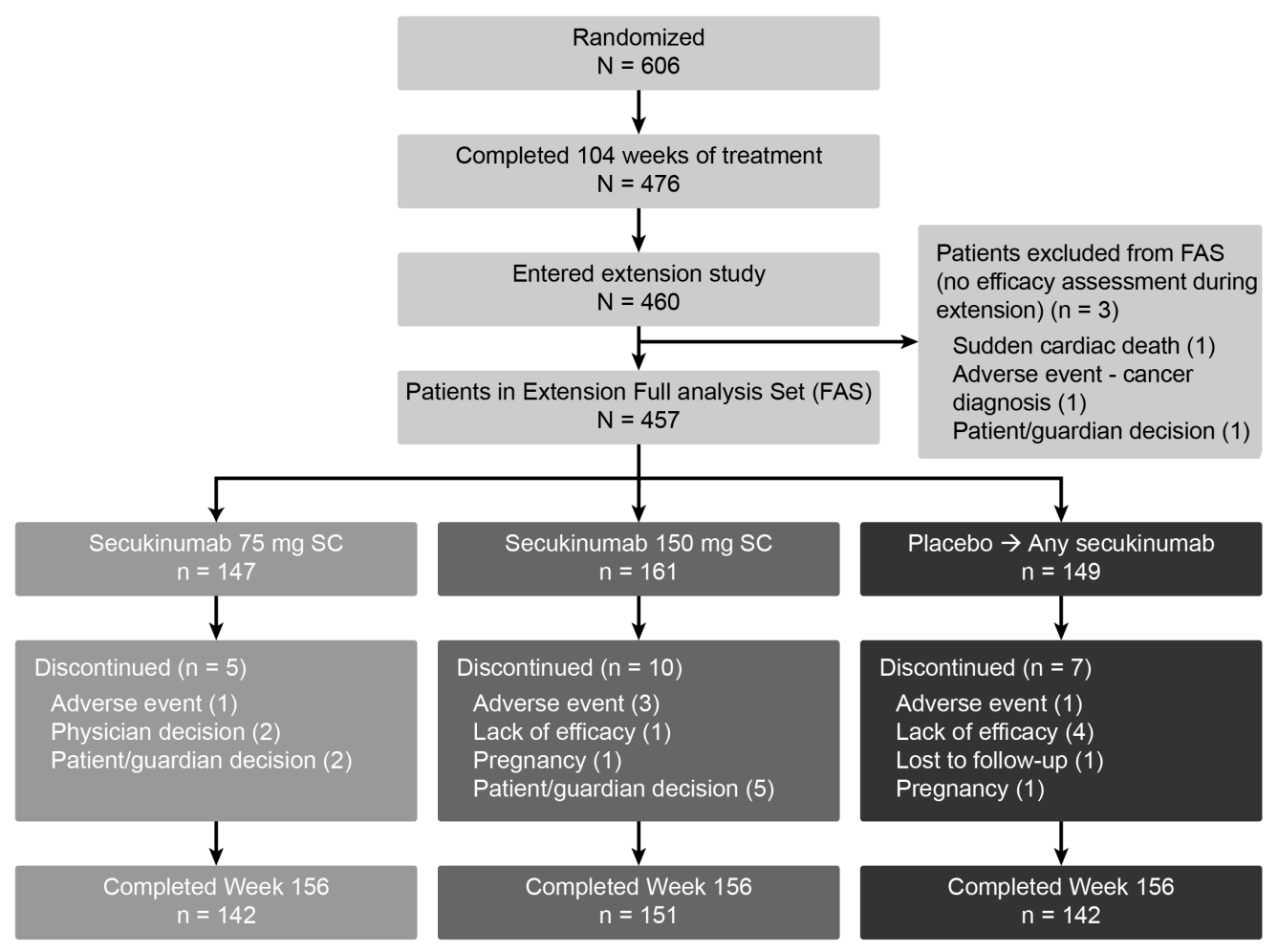

Figure 1 Patient disposition up to week 156. FAS, full analysis set; n, number of patients; SC, subcutaneous. 
Table 1 Demographics and baseline characteristics of patients originally randomised to secukinumab who entered the extension phase

\begin{tabular}{|c|c|c|}
\hline Characteristic* & $\begin{array}{l}\text { Secukinumab } \\
10 \mathrm{mg} / \mathrm{kg} \\
\mathrm{IV} \rightarrow 150 \mathrm{mg} \mathrm{SC} \\
(\mathrm{N}=161)\end{array}$ & $\begin{array}{l}\text { Secukinumab } \\
10 \mathrm{mg} / \mathrm{kg} \\
\mathrm{IV} \rightarrow 75 \mathrm{mg} \mathrm{SC} \\
(\mathrm{N}=147)\end{array}$ \\
\hline Age (years) & $49.5 \pm 11.7$ & $48.9 \pm 11.8$ \\
\hline Female, n (\%) & $83(51.6)$ & $81(55.1)$ \\
\hline Weight (kg) & $83.34 \pm 19.43$ & $83.43 \pm 19.50$ \\
\hline $\begin{array}{l}\text { Time (years) since first } \\
\text { diagnosis of PsA }\end{array}$ & $8.19 \pm 8.33$ & $7.66 \pm 8.31$ \\
\hline \multicolumn{3}{|c|}{ Disease history and baseline characteristics } \\
\hline Anti-TNF-naïve, n (\%) & $120(74.5)$ & $110(74.8)$ \\
\hline Methotrexate use, $\mathrm{n}(\%)$ & $98(60.9)$ & $91(61.9)$ \\
\hline $\begin{array}{l}\text { Systemic glucocorticoid use, } \\
\text { n (\%) }\end{array}$ & $28(17.4)$ & $22(15.0)$ \\
\hline TJC (78 joints) & $24.1 \pm 16.95$ & $21.6 \pm 15.63$ \\
\hline SJC (76 joints) & $12.7 \pm 9.81$ & $11.8 \pm 9.91$ \\
\hline $\begin{array}{l}\text { Psoriasis ( } \geq 3 \% \text { body surface } \\
\text { area), } n(\%)\end{array}$ & 89 (55.3) & $82(55.8)$ \\
\hline Presence of dactylitis, n (\%) & $83(51.6)$ & $77(52.4)$ \\
\hline Presence of enthesitis, $n(\%)$ & $99(61.5)$ & $91(61.9)$ \\
\hline
\end{tabular}

${ }^{*}$ Results are mean \pm SD unless otherwise stated.

IV, intravenous; N, number of randomised patients; n, number of patients; PsA, psoriatic arthritis; SC, subcutaneous; SJC, swollen joint count; TJC, tender joint count; TNF, tumour necrosis factor.

(table 1). For secukinumab $150 \mathrm{mg}$ and $75 \mathrm{mg}$, more than half the patients $(55.3 \%$ and $55.8 \%)$ had psoriasis affecting at least $3 \%$ of their body surface area; $51.6 \%$ and $52.4 \%$ had dactylitis and $61.5 \%$ and $61.9 \%$ had enthesitis, respectively. A total of $25.5 \%$ and $25.2 \%$ were anti-TNF-experienced; $18.6 \%$ and $16.3 \%$ had received one anti-TNF therapy and $6.8 \%$ and $8.8 \%$ had received two or more anti-TNF therapies in the secukinumab 150 $\mathrm{mg}$ and $75 \mathrm{mg}$ arms, respectively. A total of $60.9 \%$ and $61.9 \%$ were receiving concomitant methotrexate in the secukinumab $150 \mathrm{mg}$ and $75 \mathrm{mg}$ arms, respectively.

\section{Efficacy}

Out of $460(75.9 \%)$ patients who entered the extension trial, $435(95.2 \%)$ completed 156 weeks (ie, 52 weeks of the extension). Sustained improvements in efficacy were observed during this extension study, with $76.8 \%$ and $65.2 \%$ of patients treated with secukinumab $150 \mathrm{mg}$ and $75 \mathrm{mg}$ achieving an ACR20 response and 54.9/32.9\% and 39.0/26.0\% achieving ACR50/70 responses through week 156, respectively (figure $2 \mathrm{~A}$ and table 2). ACR20 response rates were sustained through week 156 , irrespective of previous anti-TNF agent exposure, with ACR20 responses achieved by $81.0 \%$ and $67.3 \%$ of anti-TNFnaïve patients and $61.5 \%$ and $55.6 \%$ of anti-TNF-experienced patients treated with secukinumab $150 \mathrm{mg}$ and 75 $\mathrm{mg}$, respectively (figure $2 \mathrm{~B}$ ). Resolution of dactylitis and enthesitis were sustained through week 156 , with $88.1 \%$ and $86.8 \%$ of patients achieving dactylitis resolution and $76.7 \%$ and $74.8 \%$ achieving enthesitis resolution in the $150 \mathrm{mg}$ and $75 \mathrm{mg}$ arms, respectively (table 2 and online supplementary figure 2). Secukinumab also demonstrated sustained improvement in PASI 75 responses and DAS28-CRP through week 156 (table 2). Proportion of patients with MDA response at week 156 was $43 \%$ and $33 \%$ in secukinumab $150 \mathrm{mg}$ and $75 \mathrm{mg}$, respectively (table 2). Improvements in physical and mental component of quality of life (SF-36 PCS and SF-36 MCS) and in physical function (HAQ-DI) were sustained over the treatment period for secukinumab $150 \mathrm{mg}$ and $75 \mathrm{mg}$ (table 2).

Results from patients with evaluable X-ray assessments demonstrated that $78.1 \%(100 / 128)$ and $74.8 \%(92 / 123)$ of patients had no radiographic progression (mTSS score $\leq 0.5$ ) from baseline to week 156, in the $150 \mathrm{mg}$ and in the $75 \mathrm{mg}$ arms, respectively (table $3 \mathrm{~A}$ ). Mean changes in mTSS score from baseline to week 156 for patients in the $150 \mathrm{mg}$ and $75 \mathrm{mg}$ arms are shown in table 3B. Subgroup analysis by anti-TNF status demonstrated that in patients with evaluable X-ray assessments, 78/100 (78.0\%) and $73 / 94(77.7 \%)$ of anti-TNF-naïve patients and 22/28 $(78.6 \%)$ and $19 / 29(65.5 \%)$ of anti- TNF-experienced patients were radiographic non-progressors in the 150 $\mathrm{mg}$ and $75 \mathrm{mg}$ groups, respectively (table 3A). Changes in mTSS score from baseline to week 156 in anti-TNFnaïve patients remained low (table $3 \mathrm{~B}$ ).

\section{Safety}

The incidence of AEs and serious AEs are presented in table 4. The EAIR per 100 patient-years of AEs in the any secukinumab $150 \mathrm{mg}$ and $75 \mathrm{mg}$ arms was 158.8 and 128.9; the rate of serious AEs was 9.3 and 6.4, respectively. The most commonly reported AEs with secukinumab were infections and infestations, musculoskeletal and connective tissue disorders and gastrointestinal disorders, which were stable over the long-term period of this study. EAIRs for serious infections and infestations, Crohn's disease, ulcerative colitis, major adverse cardiovascular events (MACE), inflammatory bowel disease and neoplasms (benign, malignant or unspecified) for secukinumab $150 \mathrm{mg}$ and $75 \mathrm{mg}$ were consistent with previous trials and are reported in table 4. Candida infections were reported in $12(\mathrm{EAIR}=1.4)$ and $5(\mathrm{EAIR}=0.7)$ patients in the any secukinumab $150 \mathrm{mg}$ and $75 \mathrm{mg}$ arms, respectively. All cases of Candida infection were mild to moderate in severity and resolved spontaneously with standard treatment or with non-drug therapy; no cases led to discontinuation of secukinumab treatment. One case of reactivation of latent tuberculosis was reported in the any secukinumab $150 \mathrm{mg}$ arm.

Deaths (spontaneous acute myocardial infarction $(n=1)$ and cardiac failure $(n=1))$ were reported in two patients with concomitant disease in the any secukinumab 150 $\mathrm{mg}$ arm. Deaths occurred in three patients in the any secukinumab $75 \mathrm{mg}$ arm including two patients (stroke 
A)

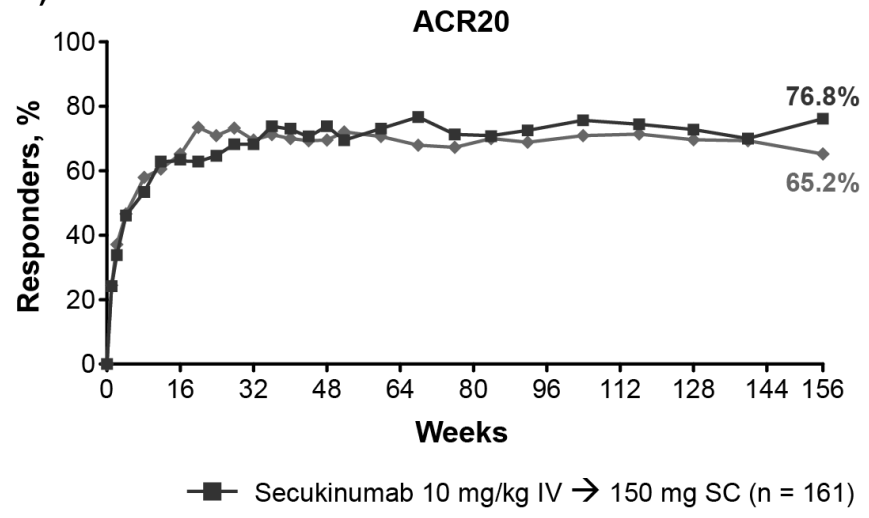

B)

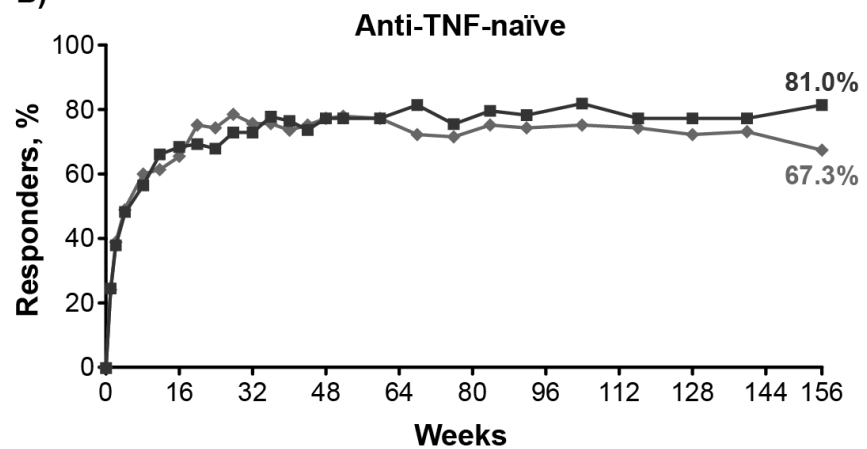

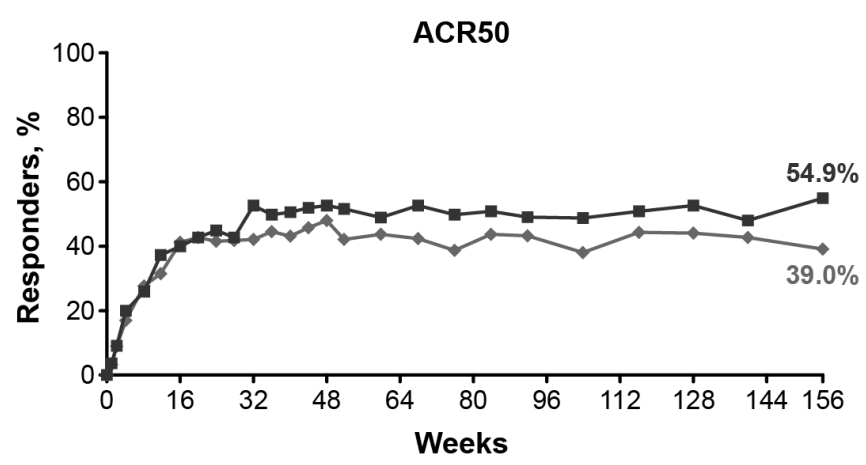

Secukinumab $10 \mathrm{mg} / \mathrm{kg} \mathrm{IV} \rightarrow 75 \mathrm{mg} \mathrm{SC}(\mathrm{n}=147)$

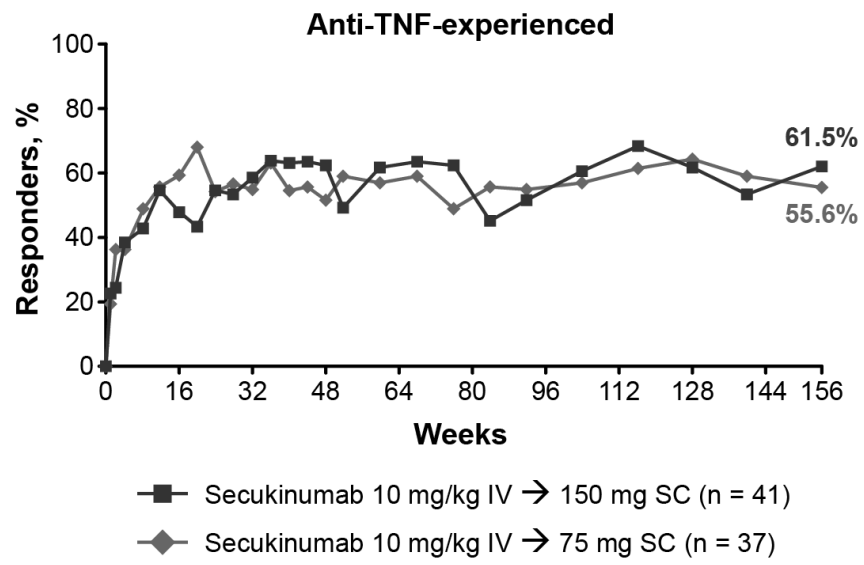

Figure 2 (A) ACR20/ACR50 response rates through week 156 in all patients originally randomised to secukinumab. (B) ACR20 response rates through week 156 in anti-TNF-nave and anti-TNF-experienced patients. Multiple imputation applied to missing variables through week 156. ACR, American College of Rheumatology; IV, intravenous; $n$, number of patients; SC, subcutaneous; TNF, tumour necrosis factor.

$(\mathrm{n}=1)$ and myocardial infarction $(\mathrm{n}=1))$ with concomitant disease and in one patient who developed squamous cell carcinoma during the study and discontinued secukinumab treatment on receiving the diagnosis.

\section{DISCUSSION}

Results from the first year of the phase III FUTURE 1 extension study have furthered our understanding of the role of secukinumab in the long-term treatment of PsA. Secukinumab demonstrated sustained improvements in the signs and symptoms, function and health-related quality of life in patients with active PsA, in addition to low rate of radiographic disease progression through 3 years of treatment. Patient retention rates throughout this trial were high with $95.2 \%$ of the FAS population completing the 156-week treatment period, supporting the sustained efficacy and tolerability of secukinumab.

These are the first 3-year findings reported for secukinumab in PsA and the data add to the growing body of evidence supporting the use of IL-17 inhibitors in PsA, as recognised in the guidelines from the European League against Rheumatism and Group for Research and
Assessment of Psoriasis and Psoriatic Arthritis management recommendations. ${ }^{727}$

Consistent with previous reports, clinical benefits with secukinumab were observed regardless of prior exposure to anti-TNF therapy, ${ }^{28}$ with better responses observed in anti-TNF-naïve patients supporting it use as a treatment for patients with PsA naïve to anti-TNF therapy and those who have experienced an inadequate response or intolerance to these agents. ${ }^{69-32}$

The IL-17 pathway plays a role in irreversible structural damage experienced during inflammatory arthritis, ${ }^{33-36}$ as indicated by the increased presence of $\mathrm{IL}-17^{+} \mathrm{CD} 8^{+}$ T-cells in the joints of patients with PsA. ${ }^{33}$ Previously published results from the FUTURE 1 study have demonstrated that secukinumab significantly inhibited radiographic progression in patients with PsA versus placebo at week $24,{ }^{37}$ with sustained inhibition through 2 years. ${ }^{16} 28$ Results reported here extend these findings up to 3 years of treatment.

The safety profile of secukinumab in this trial was consistent with previous reports in patients with PsA and moderate-to-severe plaque psoriasis, with no new 
Table 2 Secondary efficacy endpoints at weeks 52, 104 and 156 in patients originally randomised to secukinumab

\begin{tabular}{|c|c|c|c|}
\hline Variable & Week & $\begin{array}{l}\text { Secukinumab } \\
10 \mathrm{mg} / \mathrm{kg} \\
\text { IV } \rightarrow 150 \mathrm{mg} \mathrm{SC} \\
(\mathrm{N}=161)\end{array}$ & $\begin{array}{l}\text { Secukinumab } \\
10 \mathrm{mg} / \mathrm{kg} \\
\text { IV } \rightarrow 75 \mathrm{mg} \mathrm{SC} \\
(\mathrm{N}=147)\end{array}$ \\
\hline \multirow{3}{*}{$\begin{array}{l}\text { PASI } 75^{\star} \dagger, \% \\
\text { responders }\end{array}$} & 52 & 87.6 & 75.6 \\
\hline & 104 & 81.9 & 72.2 \\
\hline & 156 & 75.6 & 58.6 \\
\hline \multirow{3}{*}{$\begin{array}{l}\text { DAS28-CRP } \ddagger \text {, } \\
\text { mean change from } \\
\text { baseline } \pm S D\end{array}$} & 52 & $-1.82 \pm 1.14$ & $-1.95 \pm 1.14$ \\
\hline & 104 & $-1.81 \pm 1.23$ & $-1.86 \pm 1.22$ \\
\hline & 156 & $-1.94 \pm 1.32$ & $-1.85 \pm 1.49$ \\
\hline \multirow{3}{*}{$\begin{array}{l}\text { SF-36 PCS } \neq \text {, } \\
\text { mean change from } \\
\text { baseline } \pm S D\end{array}$} & 52 & $6.83 \pm 7.42$ & $5.87 \pm 7.04$ \\
\hline & 104 & $6.25 \pm 8.04$ & $5.33 \pm 7.22$ \\
\hline & 156 & $6.01 \pm 8.53$ & $5.50 \pm 7.27$ \\
\hline \multirow{3}{*}{$\begin{array}{l}\text { SF-36 MCS } \neq \text {, } \\
\text { mean change from } \\
\text { baseline } \pm S D\end{array}$} & 52 & $6.60 \pm 9.48$ & $4.52 \pm 8.81$ \\
\hline & 104 & $5.90 \pm 9.75$ & $4.45 \pm 8.88$ \\
\hline & 156 & $5.48 \pm 10.29$ & $3.34 \pm 9.64$ \\
\hline \multirow{3}{*}{$\begin{array}{l}\text { HAQ-DI } \neq \text {, mean } \\
\text { change from } \\
\text { baseline } \pm S D\end{array}$} & 52 & $-0.47 \pm 0.51$ & $-0.47 \pm 0.60$ \\
\hline & 104 & $-0.43 \pm 0.56$ & $-0.42 \pm 0.60$ \\
\hline & 156 & $-0.43 \pm 0.57$ & $-0.42 \pm 0.62$ \\
\hline \multirow{3}{*}{$\begin{array}{l}\text { ACR70*, \% } \\
\text { responders }\end{array}$} & 52 & 27.5 & 27.4 \\
\hline & 104 & 28.1 & 23.7 \\
\hline & 156 & 32.9 & 26.0 \\
\hline \multirow{3}{*}{$\begin{array}{l}\text { Dactylitis } \\
\text { resolution*§ (\%) }\end{array}$} & 52 & 82.0 & 84.4 \\
\hline & 104 & 86.5 & 88.6 \\
\hline & 156 & 88.1 & 86.8 \\
\hline \multirow{3}{*}{$\begin{array}{l}\text { Enthesitis } \\
\text { resolution }{ }^{\star} \S(\%)\end{array}$} & 52 & 74.8 & 75.6 \\
\hline & 104 & 74.5 & 80.3 \\
\hline & 156 & 76.7 & 74.8 \\
\hline \multirow{3}{*}{$\begin{array}{l}\mathrm{MDA}^{*}, \% \\
\text { responders }\end{array}$} & 52 & 42.5 & 37.8 \\
\hline & 104 & 40.0 & 36.5 \\
\hline & 156 & 42.9 & 33.3 \\
\hline
\end{tabular}

*Multiple imputation applied to missing variables through week 156.

†Analysis performed in randomised patients with psoriasis affecting $\geq 3 \%$ body surface area (psoriasis subset).

$\ddagger$ Observed data through week 156.

§Resolution of dactylitis and enthesitis are shown for patients with these symptoms at baseline (dactylitis: $\mathrm{N}=83(150 \mathrm{mg})$ and 77 (75 mg); enthesitis: $\mathrm{N}=99$ (150 mg) and 91 (75 mg). Results are mean $\pm S D$ unless otherwise stated.

ACR, American College of Rheumatology; DAS28-CRP,

Disease Activity Score in 28 joints using C-reactive protein;

HAQ-DI, Health Assessment Questionnaire-Disability Index; IV, intravenous; MCS, mental component summary; MDA, minimal disease activity; N, number of randomised patients; PASI, Psoriasis Area and Severity Index; PCS, physical component summary; SC, subcutaneous; SF-36, medical outcomes study 36-item Short Form-36 Health Survey.

or unexpected safety signals observed. ${ }^{15-17}$ The most common AEs observed (infections and infestations, musculoskeletal and connective tissue disorders, and gastrointestinal disorders) and serious AEs are consistent

\begin{tabular}{|c|c|c|}
\hline & $\begin{array}{l}\text { Secukinumab } \\
10 \mathrm{mg} / \mathrm{kg} \mathrm{IV} \rightarrow 150 \\
\mathrm{mg} \mathrm{SC} \\
(\mathrm{N}=161)\end{array}$ & $\begin{array}{l}\text { Secukinumab } \\
10 \mathrm{mg} / \mathrm{kg} \mathrm{IV} \rightarrow 75 \\
\mathrm{mg} \mathrm{SC} \\
(\mathrm{N}=147)\end{array}$ \\
\hline $\begin{array}{l}\text { Radiographic non- } \\
\text { progressors, n/M (\%) }\end{array}$ & $100 / 128(78.1)$ & $92 / 123(74.8)$ \\
\hline $\begin{array}{l}\text { Anti-TNF-naïve } \\
\text { patients }\end{array}$ & 78/100 (78.0) & 73/94 (77.7) \\
\hline $\begin{array}{l}\text { Anti-TNF-experienced } \\
\text { patients }\end{array}$ & 22/28 (78.6) & $19 / 29(65.5)$ \\
\hline
\end{tabular}

IV, intravenous; M, number of patients who have a nonmissing response status in the treatment group; $n$, number of patients who are non-progression responders (non-progression responders were patients with a change from baseline of $\leq 0.5$ in van der Heijde modified Total Sharp Score during the considered period); SC, subcutaneous; TNF, tumour necrosis factor.

with data from previous reports in patients receiving secukinumab and placebo. ${ }^{16}$

Patients with PsA have been reported to have a possible elevated risk of cardiovascular disease ${ }^{38-40}$ when treated with anti-IL-12/23 agents, ${ }^{41} 42$ and thus cardiovascular AEs are of interest in patients treated with biological agents. In our study, the EAIRs of MACE were 0.3 and 0.8 in the any secukinumab $150 \mathrm{mg}$ and $75 \mathrm{mg}$ groups, respectively. This is in line with previously reported rates of MACE in secukinumab-treated patients, including those from the FUTURE 1 core study, ${ }^{15} 1628$ and corroborate results from a recent meta-analysis showing a low overall MACE rate in patients with psoriasis who were treated with the IL-17A inhibitors, secukinumab and ixekizumab. ${ }^{43}$ Candida infections observed during this study are consistent with results from phase III studies, including the FUTURE 1 core study, in patients with $\mathrm{PsA}^{1728}$ and psoriasis. ${ }^{15}$ All cases were mild to moderate in severity, did not lead to discontinuation and were managed with standard antifungal therapy. Increased rate of Candida infections is likely attributable to the role of IL-17 in host defense against fungal infections, particularly at mucosal sites. ${ }^{44}$ Other AEs of special interest in this study, including Crohn's disease and ulcerative colitis, were low and in line with previously reported findings, including those from the FUTURE 1 core study. ${ }^{1620}$ They also confirm results from a recent review of phase II and III studies where patients with PsA treated with secukinumab (up to 112 weeks) had EAIRs of 0.07 for Crohn's disease and 0.14 for ulcerative colitis. ${ }^{45}$ No suicides or suicide ideation were reported during this study.

While this study was not specifically designed to examine the psychological impact of secukinumab treatment on patients with PsA, an improvement in emotional role functioning and mental health was observed with secukinumab treatment, as assessed by the patient-reported SF-36 MCS. ${ }^{46}$

Limitations of this study included a lack of a long-term comparator due to the fact that long-term treatment with 
Table 3B Mean change in X-ray assessments from baseline to week 156 (mTSS score, erosion score and JSN score-evaluable cases, observed data)

\begin{tabular}{|c|c|c|c|}
\hline $\begin{array}{l}\text { X-ray } \\
\text { measurement* }\end{array}$ & & $\begin{array}{l}\text { Secukinumab } \\
10 \mathrm{mg} / \mathrm{kg} \\
\mathrm{IV} \rightarrow 150 \mathrm{mg} \mathrm{SC} \\
(\mathrm{N}=161)\end{array}$ & $\begin{array}{l}\text { Secukinumab } \\
10 \mathrm{mg} / \mathrm{kg} \\
\mathrm{IV} \rightarrow 75 \mathrm{mg} \text { SC } \\
(\mathrm{N}=147)\end{array}$ \\
\hline \multicolumn{4}{|l|}{ Overall } \\
\hline $\begin{array}{l}\text { No of patients } \\
\text { evaluated }\end{array}$ & & 128 & 123 \\
\hline \multirow[t]{2}{*}{ mTSS score } & Baseline & $16.9 \pm 34.52$ & $16.3 \pm 32.30$ \\
\hline & Change† & $1.9 \pm 8.49$ & $2.0 \pm 6.44$ \\
\hline \multirow[t]{2}{*}{ Erosion score } & Baseline & $8.1 \pm 16.88$ & $7.7 \pm 14.63$ \\
\hline & Change† & $1.1 \pm 5.31$ & $1.0 \pm 3.57$ \\
\hline \multirow[t]{2}{*}{ JSN score } & Baseline & $8.8 \pm 18.36$ & $8.6 \pm 18.43$ \\
\hline & Change† & $0.8 \pm 3.54$ & $1.0 \pm 3.42$ \\
\hline $\begin{array}{l}\text { Anti-TNF-naïve } \\
\text { patients }\end{array}$ & & $(\mathrm{N}=120)$ & $(\mathrm{N}=110)$ \\
\hline $\begin{array}{l}\text { No of patients } \\
\text { evaluated }\end{array}$ & & 100 & 94 \\
\hline \multirow[t]{2}{*}{ mTSS score } & Baseline & $13.1 \pm 28.35$ & $12.5 \pm 30.80$ \\
\hline & Change† & $1.1 \pm 4.49$ & $1.4 \pm 5.29$ \\
\hline \multirow[t]{2}{*}{ Erosion score } & Baseline & $6.7 \pm 14.67$ & $5.8 \pm 13.80$ \\
\hline & Change† & $0.7 \pm 3.66$ & $0.7 \pm 2.80$ \\
\hline \multirow[t]{2}{*}{ JSN score } & Baseline & $6.4 \pm 14.30$ & $6.7 \pm 17.58$ \\
\hline & Change† & $0.4 \pm 1.16$ & $0.7 \pm 2.78$ \\
\hline $\begin{array}{l}\text { Anti-TNF- } \\
\text { experienced } \\
\text { patients }\end{array}$ & & $(\mathrm{N}=41)$ & $(\mathrm{N}=37)$ \\
\hline $\begin{array}{l}\text { No of patients } \\
\text { evaluated }\end{array}$ & & 28 & 29 \\
\hline \multirow[t]{2}{*}{ mTSS score } & Baseline & $30.5 \pm 49.09$ & $28.5 \pm 34.51$ \\
\hline & Change† & $5.1 \pm 15.88$ & $4.1 \pm 9.07$ \\
\hline \multirow[t]{2}{*}{ Erosion score } & Baseline & $13.3 \pm 22.72$ & $13.8 \pm 15.81$ \\
\hline & Change† & $2.7 \pm 8.96$ & $2.2 \pm 5.25$ \\
\hline \multirow[t]{2}{*}{ JSN score } & Baseline & $17.2 \pm 27.21$ & $14.8 \pm 20.08$ \\
\hline & Change† & $2.4 \pm 7.11$ & $1.8 \pm 4.93$ \\
\hline
\end{tabular}

Values are as mean \pm SD.

*Observed data.

${ }^{\dagger}$ Change from baseline to week 156 . Only patients with a value at each time point are presented.

IV, intravenous; JSN, joint space narrowing; mTSS, van der Heijde modified total Sharp score; N, total number of patients in specified group; SC, subcutaneous; TNF, tumour necrosis factor.

placebo is considered unethical; the placebo-controlled period of the core trial was, therefore, only up to week 16. There was no active comparator included and results could be potentially biased as patients remaining in the study are those patients benefiting from secukinumab. While efficacy responses in the current study were sustained irrespective of previous anti-TNF exposure, patients eligible for inclusion in this study could have
Table 4 AEs and serious AEs across entire treatment period

\begin{tabular}{|c|c|c|}
\hline AEs & $\begin{array}{l}\text { Any } \\
\text { secukinumab } \\
150 \mathrm{mg}^{*} \\
(\mathrm{~N}=434)\end{array}$ & $\begin{array}{l}\text { Any } \\
\text { secukinumab } \\
75 \mathrm{mg}^{*} \\
(\mathrm{~N}=292)\end{array}$ \\
\hline $\begin{array}{l}\text { Exposure to study treatment } \\
\text { (days), mean } \pm S D\end{array}$ & $754.0 \pm 509.4$ & $940.1 \pm 340.3$ \\
\hline Death, n (\%) & $2(0.5)$ & $3(1.0)$ \\
\hline $\begin{array}{l}\text { Discontinuation due to AEs, } \\
n(\%)\end{array}$ & $20(4.6)$ & $20(6.8)$ \\
\hline Any AEs, n (EAIR) & $321(158.8)$ & $248(128.9)$ \\
\hline Any serious AEs, n (EAIR) & $73(9.3)$ & $45(6.4)$ \\
\hline \multicolumn{3}{|l|}{ AEs of special interest, $n$ (EAIR) } \\
\hline $\begin{array}{l}\text { Serious infections and } \\
\text { infestations }\end{array}$ & $15(1.7)$ & $12(1.6)$ \\
\hline Candida infections & $12(1.4)$ & $5(0.7)$ \\
\hline Crohn's disease & $0(0)$ & $2(0.3)$ \\
\hline Ulcerative colitis & $0(0)$ & $1(0.1)$ \\
\hline MACE & $3(0.3)$ & $6(0.8)$ \\
\hline
\end{tabular}

*Includes all patients who were administered with at least one dose of study treatment during the core or the extension study. Patients who were up-titrated $(\mathrm{N}=139)$ were counted in either secukinumab groups depending on the timing of the event. If a patient experienced an $\mathrm{AE}$ after up-titration, the corresponding $A E$ was counted at the up-titrated dose.

$A E$ data presented as $n$ (EAIR per 100 patient-years) unless otherwise stated.

$\mathrm{AE}$, adverse event; EAIR, exposure-adjusted incidence rate; IV, intravenous; MACE, major adverse cardiac events; SC, subcutaneous.

been treated with no more than three anti-TNF agents; this may be viewed as a limitation of the study.

In summary, secukinumab provided sustained improvements across multiple domains of PsA including signs and symptoms, quality of life and physical function in patients with active disease, in addition to low rate of radiographic disease progression through 3 years of treatment. The results confirmed a favourable and consistent safety profile through 3 years, which is comparable with that reported through 2 years in the core trial. Overall, the results of this extension study provide further supporting evidence for the long-term use of secukinumab in the treatment of patients with PsA.

Author affiliations

${ }^{1}$ Swedish Medical Centre and University of Washington, Seattle, Washington, USA ${ }^{2}$ University of California San Diego School of Medicine, La Jolla, California, USA ${ }^{3}$ Dallas VAMC and University of Texas Southwestern Medical Center, Dallas, Texas, USA

${ }^{4}$ Barts Health NHS Trust, London, UK

${ }^{5}$ University of Erlangen-Nuremberg, Erlangen, Germany

${ }^{6}$ Monash University, Melbourne, Victoria, Australia

${ }^{7}$ University of Hasselt, Hasselt, Belgium

${ }^{8}$ Maastricht University Hospital, Maastricht, The Netherlands

${ }^{9}$ Novartis Pharma AG, Basel, Switzerland

${ }^{10}$ Novartis Pharmaceuticals Corporation, East Hanover, New Jersey, USA 
Acknowledgements This analysis was supported by Novartis Pharmaceuticals Corporation. The authors thank Gillian Brodie, Novartis Ireland Ltd, Ireland and Niladri Maity, Novartis, India for providing medical writing support, which was funded by Novartis in accordance with Good Publication Practice (GPP3) guidelines

Contributors All authors participated in the interpretation of data, critical review and final approval of the manuscript.

Funding The study was sponsored by Novartis Pharma AG, Basel, Switzerland, and designed by the scientific steering committee and Novartis personnel. Medical writing support was funded by Novartis.

Competing interests PJM has received research grants from AbbVie, BMS, Celgene, Janssen, Lilly, Novartis, Pfizer, SUN, and UCB; consulting fees from AbbVie, Amgen, BMS, Celgene, Covagen, Crescendo , Janssen, LEO, Lilly, Merck, Novartis, Pfizer, SUN and UCB; and speakers' bureau fees for AbbVie, Amgen, BMS, Celgene, Genentech, Janssen, Lilly, Pfizer and UCB. AK served as consultant for Novartis. AR has received research grants from Janssen, Novartis, Pfizer and AbbVie; and consulting fees from Lilly. HT served as consultant or participation in advisory boards for AbbVie, Novartis, Pfizer, UCB, Eli-Lilly, Janssen Education Grants, Novartis and Pfizer. JR received speaker fees from AbbVie, AstraZeneca, Biogen, BMS, Celgene, Chugai, GSK, Janssen, MSD, Novartis, Pfizer, Roche, Sanofi Aventis and UCB; consulting fees from AbbVie, AstraZeneca, Biogen, BMS, Chugai, MSD, Novartis, Pfizer, Roche, Sanofi Aventis and UCB. PG participated in clinical studies, advisory boards, received speaker's fees from Abbott, Amgen, BMS, Lilly, MSD, Novartis, Pfizer, Roche, UCB and Will-Pharma. PP is an employee of Novartis with Novartis stock. EMD is an employee of Novartis. SM is an employee of Novartis, with Novartis stock. LP is an employee of Novartis with Novartis stock.

Patient consent Obtained.

Ethics approval This study was approved by the institutional review board or ethics committee at each participating site (Swedish Medical Centre and University of Washington (1143210), Dallas VAMC and University of Texas Southwestern Medical Center (IRB no. 14-025), Barts Health NHS Trust (13/WM/0365), University of Erlangen-Nuremberg (AZ: EK-13/081), Monash University (2013-08-423), University of Hasselt and Maastricht University Hospital (2013/1062); online supplementary table 1) and was conducted according to the Declaration of Helsinki.

Provenance and peer review Not commissioned; externally peer reviewed.

Data statement Novartis is committed to sharing with qualified external researchers, access to patient-level data and supporting clinical documents from eligible studies. These requests are reviewed and approved by an independent review panel on the basis of scientific merit. All data provided is anonymized to respect the privacy of patients who have participated in the trial in line with applicable laws and regulations.

Open access This is an Open Access article distributed in accordance with the Creative Commons Attribution Non Commercial (CC BY-NC 4.0) license, which permits others to distribute, remix, adapt, build upon this work non-commercially, and license their derivative works on different terms, provided the original work is properly cited and the use is non-commercial. See: http://creativecommons.org/ licenses/by-nc/4.0/

\section{REFERENCES}

1. Ritchlin CT, Kavanaugh A, Gladman DD, et al. Treatment recommendations for psoriatic arthritis. Ann Rheum Dis 2009;68:1387-94.

2. Jamnitski A, Symmons D, Peters MJ, et al. Cardiovascular comorbidities in patients with psoriatic arthritis: a systematic review. Ann Rheum Dis 2013;72:211-6.

3. Boehncke WH, Menter A. Burden of disease: psoriasis and psoriatic arthritis. Am J Clin Dermatol 2013;14:377-88.

4. van der Horst-Bruinsma IE, Nurmohamed MT. Management and evaluation of extra-articular manifestations in spondyloarthritis. Ther Adv Musculoskelet Dis 2012:4:413-22.

5. Kavanaugh A, Helliwell P, Ritchlin CT. Psoriatic arthritis and burden of disease: patient perspectives from the population-based Multinational Assessment of Psoriasis and psoriatic arthritis (MAPP) Survey. Rheumatol Ther 2016;3:91-102.

6. Mease PJ, Armstrong AW. Managing patients with psoriatic disease: the diagnosis and pharmacologic treatment of psoriatic arthritis in patients with psoriasis. Drugs 2014;74:423-41.

7. Gossec L, Smolen JS, Ramiro S, et al. European League Against Rheumatism (EULAR) recommendations for the management of psoriatic arthritis with pharmacological therapies: 2015 update. Ann Rheum Dis 2016;75:499-510.
8. Coates LC, Tillett W, Chandler D, et al. The 2012 BSR and BHPR guideline for the treatment of psoriatic arthritis with biologics. Rheumatology 2013;52:1754-7.

9. Mease P. Psoriatic arthritis and spondyloarthritis assessment and management update. Curr Opin Rheumatol 2013;25:287-96.

10. Gossec L, Smolen JS, Gaujoux-Viala C, et al. European League Against Rheumatism recommendations for the management of psoriatic arthritis with pharmacological therapies. Ann Rheum Dis 2012;71:4-12.

11. American Academy of Dermatology Work Group, Menter A, Korman $\mathrm{NJ}$, et al. Guidelines of care for the management of psoriasis and psoriatic arthritis: section 6. Guidelines of care for the treatment of psoriasis and psoriatic arthritis: case-based presentations and evidence-based conclusions. J Am Acad Dermatol 2011;65:137-74.

12. Gladman DD, Antoni $C$, Mease $P$, et al. Psoriatic arthritis: epidemiology, clinical features, course, and outcome. Ann Rheum Dis 2005;64(Suppl 2):ii14-7.

13. Baeten D, Baraliakos X, Braun J, et al. Anti-interleukin-17A monoclonal antibody secukinumab in treatment of ankylosing spondylitis: a randomised, double-blind, placebo-controlled trial. Lancet 2013;382:1705-13.

14. Baeten D, Sieper J, Braun J, et al. Secukinumab, an interleukin-17a inhibitor, in ankylosing spondylitis. N Engl J Med 2015;373:2534-48.

15. Langley RG, Elewski BE, Lebwohl M, et al. Secukinumab in plaque psoriasis - results of two phase 3 trials. N Engl J Med 2014;371:326-38.

16. Mease PJ, McInnes IB, Kirkham B, et al. Secukinumab inhibition of interleukin-17A in patients with psoriatic arthritis. N Engl $J$ Med 2015;373:1329-39

17. Mclnnes IB, Mease PJ, Kirkham B, et al. Secukinumab, a human anti-interleukin-17A monoclonal antibody, in patients with psoriatic arthritis (FUTURE 2): a randomised, double-blind, placebocontrolled, phase 3 trial. Lancet 2015;386:1137-46.

18. Mclnnes IB, Sieper J, Braun J, et al. Efficacy and safety of secukinumab, a fully human anti-interleukin-17A monoclonal antibody, in patients with moderate-to-severe psoriatic arthritis: a 24-week, randomised, double-blind, placebo-controlled, phase II proof-of-concept trial. Ann Rheum Dis 2014;73:349-56.

19. Hueber W, Patel DD, Dryja T, et al. Effects of AIN457, a fully human antibody to interleukin-17A, on psoriasis, rheumatoid arthritis, and uveitis. Sci Trans/ Med 2010;2:ra72.

20. Baraliakos X, Kivitz AJ, Deodhar AA, et al. Long-term effects of interleukin-17A inhibition with secukinumab in active ankylosing spondylitis: 3-year efficacy and safety results from an extension of the phase 3 MEASURE 1 trial. Clin Exp Rheumatol 2018;36:50-5.

21. Kavanaugh A, McInnes IB, Mease PJ, et al. Efficacy of subcutaneous secukinumab in patients with active psoriatic arthritis stratified by prior tumor necrosis factor inhibitor use: results from the randomized placebo-controlled FUTURE 2 Study. J Rheumatol 2016;43:1713-7.

22. Taylor W, Gladman D, Helliwell P, et al. Classification criteria for psoriatic arthritis: development of new criteria from a large international study. Arthritis Rheum 2006:54:2665-73.

23. WMA Declaration of Helsinki-ethical principles for medical research involving human subjects. 2013

24. Felson DT, Anderson JJ, Boers M. Preliminary definition of improvement in rheumatoid arthritis. Arthritis Rheum 1995;38:727-35.

25. van der Heijde D, Sharp J, Wassenberg S, et al. Psoriatic arthritis imaging: a review of scoring methods. Ann Rheum Dis 2005;64(Suppl 2):ii61-4.

26. van der Heijde D, Simon L, Smolen J, et al. How to report radiographic data in randomized clinical trials in rheumatoid arthritis: guidelines from a roundtable discussion. Arthritis Rheum 2002;47:215-8.

27. Coates LC, Kavanaugh A, Mease PJ, et al. Group for research and assessment of psoriasis and psoriatic arthritis 2015 treatment recommendations for psoriatic arthritis. Arthritis Rheumatol 2016:68:1060-71.

28. Kavanaugh A, Mease PJ, Reimold AM, et al. Secukinumab for long-term treatment of psoriatic arthritis: a two-year follow-up from a phase III, randomized, double-blind placebo-controlled study. Arthritis Care Res 2017;69:347-55.

29. Saad AA, Ashcroft DM, Watson KD, et al. Persistence with antitumour necrosis factor therapies in patients with psoriatic arthritis: observational study from the British Society of Rheumatology Biologics Register. Arthritis Res Ther 2009;11:R52.

30. Glintborg B, Ostergaard M, Krogh NS, et al. Clinical response, drug survival, and predictors thereof among 548 patients with psoriatic arthritis who switched tumor necrosis factor $\alpha$ inhibitor therapy: results from the Danish Nationwide DANBIO Registry. Arthritis Rheum 2013:65:1213-23. 
31. Kavanaugh A, Krueger GG, Beutler A, et al. Infliximab maintains a high degree of clinical response in patients with active psoriatic arthritis through 1 year of treatment: results from the IMPACT 2 trial. Ann Rheum Dis 2007;66:498-505.

32. Fagerli KM, Lie E, van der Heijde D, et al. Switching between TNF inhibitors in psoriatic arthritis: data from the NOR-DMARD study. Ann Rheum Dis 2013;72:1840-4.

33. Menon B, Gullick NJ, Walter GJ, et al. Interleukin-17+CD8+ T cells are enriched in the joints of patients with psoriatic arthritis and correlate with disease activity and joint damage progression. Arthritis Rheumatol 2014;66:1272-81.

34. Bush KA, Farmer KM, Walker JS, et al. Reduction of joint inflammation and bone erosion in rat adjuvant arthritis by treatment with interleukin-17 receptor IgG1 Fc fusion protein. Arthritis Rheum 2002;46:802-5.

35. Lubberts E, Koenders MI, Oppers-Walgreen B, et al. Treatment with a neutralizing anti-murine interleukin-17 antibody after the onset of collagen-induced arthritis reduces joint inflammation, cartilage destruction, and bone erosion. Arthritis Rheum 2004;50:650-9.

36. Pöllinger B, Junt T, Metzler B, et al. Th17 cells, not IL-17+ $\gamma \delta$ T cells, drive arthritic bone destruction in mice and humans. $J$ Immunol 2011;186:2602-12.

37. van der Heijde D, Landewé RB, Mease PJ, et al. Brief report: secukinumab provides significant and sustained inhibition of joint structural damage in a phase III study of active psoriatic arthritis. Arthritis Rheumatol 2016;68:1914-21.

38. Edson-Heredia E, Zhu B, Lefevre C, et al. Prevalence and incidence rates of cardiovascular, autoimmune, and other diseases in patients with psoriatic or psoriatic arthritis: a retrospective study using clinical practice research datalink. J Eur Acad Dermatol Venereol 2015;29:955-63.

39. Husted JA, Thavaneswaran A, Chandran V, et al. Cardiovascular and other comorbidities in patients with psoriatic arthritis: a comparison with patients with psoriasis. Arthritis Care Res 2011;63:1729-35.

40. Moltó A, Nikiphorou E. Comorbidities in spondyloarthritis. Front Med 2018;5:62.

41. Gordon KB, Langley RG, Gottlieb AB, et al. A phase III, randomized, controlled trial of the fully human IL-12/23 mAb briakinumab in moderate-to-severe psoriasis. J Invest Dermatol 2012;132:304-14.

42. Krueger GG, Langley RG, Leonardi C, et al. A human interleukin-12/23 monoclonal antibody for the treatment of psoriasis. N Engl J Med 2007;356:580-92.

43. Rungapiromnan W, Yiu ZZN, Warren RB, et al. Impact of biologic therapies on risk of major adverse cardiovascular events in patients with psoriasis: systematic review and meta-analysis of randomized controlled trials. Br J Dermatol 2017;176:890-901.

44. Miossec P, Korn T, Kuchroo VK. Interleukin-17 and type 17 helper T cells. N Engl J Med 2009;361:888-98.

45. Schreiber S, Sands BE, Deodhar A, et al. OP0113 No Increased incidence of inflammatory bowel disease among secukinumabtreated patients with moderate to severe psoriasis, psoriatic arthritis, or ankylosing spondylitis: data from 14 phase 2 and phase 3 clinical studies. Ann Rheum Dis 2016;75(Suppl 2):97-8.

46. Jenkinson C, Stewart-Brown S, Petersen S, et al. Assessment of the SF-36 version 2 in the United Kingdom. J Epidemiol Community Health 1999;53:46-50. 
Correction: Secukinumab in the treatment of psoriatic arthritis: efficacy and safety results through 3 years from the year 1 extension of the randomised phase III FUTURE 1 trial

Mease PJ, Kavanaugh A, Reimold A, et al. Secukinumab in the treatment of psoriatic arthritis: efficacy and safety results through 3 years from the year 1 extension of the randomised phase III FUTURE 1 trial. RMD Open 2018;4:e00723. doi: 10.1136/ rmdopen-2018-000723corr1

The authors noticed a potential data inconsistency in the published version. The statement regarding the tuberculosis needs to be updated in the first paragraph of the 'Safety' sub-section under the 'Results' section (page 4).

The corrected information on tuberculosis is: No new cases of tuberculosis, and noreactivation of latent tuberculosis were reported.

Open access This is an Open Access article distributed in accordance with the Creative Commons Attribution Non Commercial (CC BY-NC 4.0) license, which permits others to distribute, remix, adapt, build upon this work non-commercially, and license their derivative works on different terms, provided the original work is properly cited and the use is non-commercial. See: http://creativecommons.org/licenses/by-nc/4.0/

C Author(s) (or their employer(s)) 2018. Re-use permitted under CC BY-NC. No commercial re-use. See rights and permissions. Published by BMJ.

RMD Open 2018;4:e000723corr1. doi:10.1136/rmdopen-2018-000723corr1

(A) Check for updates 